\title{
Rewitalizacja terenów pomilitarnych jako nowy wymiar współczesnego sensu miasta. Analiza przypadku Twierdzy Ehrenbreitstein w Koblencji
} Revitalization of post military areas as a new aspect of the contemporary sense of the city. Case study of the Ehrenbreitstein Fortress in Coblenz

\section{Streszczenie}

Twierdza Ehrenbreitstein w Koblencji to zespół fortyfikacji pruskich wzniesiony z początkiem XIX wieku. Po deklasyfikacji twierdzy obiekty miały zostać rozebrane, jednak zauważono istotną wartość i znaczenie kulturowe. Podstawowymi celami artykułu jest poznanie prawidłowo funkcjonującego przykładu zrewitalizowanej twierdzy w Koblencji, jej wpływu na rozwój miasta na przestrzeni wieków, ale też określenie wartości przedsięwzięcia rewitalizacji w aspekcie ekonomicznym, społecznym i architektonicznym.

Słowa kluczowe: rewitalizacja, tereny powojskowe (pomilitarne), sens miasta

\section{Abstract}

Ehrenbreitstein Frotress in Koblenz is a complex of Prussian fortifications erected at the begnining of the $19^{\text {th }}$ century. After declassification of fortress, all buildings and elements were intended for demolition. Fortunately, value and cultural significance were noted. Main aim of article is to get acquainted with properly functioning example of the revitalized fortress in Koblenz and its influence on the development of the city over the centuries. There is also conducted an attempt to identify the value of the revitalization project in a sense of economy, social and architectural aspects.

Keywords: revitalization, post military areas, sense of city 


\section{WPROWADZENIE}

Gwałtowny rozwój przemysłu, technologii oraz informatyki mający swój początek w II połowie XX wieku przyczynił się do bezpośredniego wzrostu i przyspieszenia światowej konsumpcji, a co za tym idzie postępu gospodarczego. To również czas całkowitej zmiany funkcjonowania sił zbrojnych, metod działania i możliwości logistycznych, które na zawsze zmieniły sposób prowadzenia wojen. W efekcie w XXI wieku wiele terenów, niegdyś niezbędnych do funkcjonowania i obrony państw, straciło swoje prymarne przeznaczenie i stało się nieużytkiem - są to obszary powojskowe. Często są to tereny całkowicie opuszczone, zdegradowane i wykluczone z nowych inwestycji. Niestety takie podejście sukcesywnie obniża ich wartość w kontekście lokalnym i ponadlokalnym. O ile w przypadku założeń fortyfikacyjnych z okresów starożytności, średniowiecza czy renesansu nie ma powodu do zaniepokojenia, gdyż zostały już docenione i najczęściej są wpisane na listę światowego dziedzictwa UNESCO (np. Twierdza Suomenlinna, Twierdza Tower w Londynie, Mont Saint-Michel), to XIX-wieczne pomilitarne układy przestrzenne pozostają zapomniane. W przypadku Polski te układy są wynikiem intensywnych działań wojennych trzech zaborców: Prus, Austrii i Rosji. W konsekwencji w Polsce znajduje się znaczna liczba pozostałości różnych systemów fortyfikacji oraz obiektów wojskowych, które ulegają powolnej degradacji. Dlatego też istotne jest bliższe poznanie i zbadanie problemu ${ }^{1}$.

Mimo iż polskie XIX-wieczne tereny pomilitarne nadal częściowo podlegają kontroli wojskowej i mają ograniczone możliwości dostępu, to w przeciągu ostatniej dekady stały się przedmiotem szybko postępujących zmian inwestycyjnych. Ponadto, obiekty i układy przestrzenne, które są wpisane do rejestru zabytków, mogą być bonifikatowane nawet w 50\%. W tych dynamicznych okolicznościach ważna jest trafna diagnoza polskich obszarów pomilitarnych, na których planowane są inwestycje. Rozważania te powinny być rozpatrywane ze szczególnym uwzględnieniem genius loci i tożsamości miejsca, co dodatkowo może podnieść wartość przyszłych inwestycji.

Fortyfikacje nowożytne wieku XIX reprezentują okres sztuki obronnej głównych twierdz i obszarów warownych. Są to systemy: kleszczowy, poligonalny, fortowy ześrodkowany, fortowy grupowy oraz fortyfikacji rozproszonej. Twierdze XIX wieku często były budowane wokół rdzenia, powstałego we wcześniejszych wiekach, jednak w kontekście przyjętego zakresu tematycznego zostaną pominięte. Można wyróżnić wiele szkół fortyfikacyjnych, zależnych od ustroju politycznego, jednak wszystkie bazowały na tych samych pryncypiach. Jednym z ważniejszych, jeśli nie najważniejszym, jest lokalizacja. Są bardzo dobrze usytuowane, przy strategicznych węzłach komunikacyjnych (lądowych oraz śródlądowych). W konsekwencji to obszary o szczególnych wartościach przyrodniczych i krajobrazowych (ujścia rzek, zróżnicowana topografia terenu, naturalne bariery w formie urwisk, skał, klifów i innych).

Jedną z dróg rozwiązujących problem degradacji XIX-wiecznych terenów powojskowych jest rewitalizacja. Dzięki niej wiele obszarów zyskało nowe oblicza, które współcześnie są przykładem bardzo dobrego funkcjonowania przestrzeni zrewitalizowanych. Projekty te opierają się 
na kompleksowym, korzystnym przekształceniu obszarów zdegradowanych w atrakcyjne przestrzenie urbanistyczne, architektoniczne, a przede wszystkim społeczne. Co więcej, polegają na zintegrowaniu ich z pozostałymi, dobrze funkcjonującymi częściami miasta, czego efektem jest jeden, spójny oraz funkcjonalny organizm miejski. Na świecie podobne obszary powojskowe są zagospodarowane i stanowią przykład godny naśladowania. Bywa, że byłe tereny wojskowe służące do celów wojennych są „wchłonięte” do struktury miasta, czego doskonałym przykładem są Pola Marsowe w Paryżu. Obszar, który pierwotnie był terenem ćwiczeń wojskowych i mógł być całkowicie zabudowany - nie został i stał się jedną z wizytówek stolicy Francji.

Podstawowymi celami artykułu jest przeanalizowanie prawidłowo funkcjonującego przykładu zrewitalizowanej twierdzy w Koblencji, jej roli w rozwoju miasta na przestrzeni wieków, ale też określenie wartości przedsięwzięcia rewitalizacji w aspekcie ekonomicznym, społecznym i architektonicznym. Wnioski z przeprowadzonego badania, będące dowodem na słuszność podjętych działań z zakresu interwencji planistyczno-architektonicznych na terenach powojskowych, mogą być również swego rodzaju drogowskazem w postępowaniu z polskimi XIX-wiecznymi terenami powojskowymi.

\section{ANALIZA PRZYPADKU - TWIERDZA EHRENBREITSTEIN W KOBLENCJI}

\subsection{ZARYS HISTORYCZNY ROZWOJU MIASTA I TWIERDZY}

Koblencja położona jest w zachodniej części Niemiec, w kraju związkowym Nadrenia-Palatynat, najbliższe większe miasta to Bonn (60 km) i Mainz (90 km). Geograficznie znajduje się przy ujściu rzeki Mozela do Renu. Miasto słynie z regularnych imprez, do ważniejszych należy zaliczyć: festiwal kwiatowy i wina (przełom kwietnia i maja), dni kultury twierdzy Ehrenbreitstein (maj), Old Town Festival (lipiec), Ren w płomieniach (sierpień, każda druga sobota), World Music Festival Horizonte - festiwal muzyki alternatywnej (lipiec). Tutaj można też znaleźć najwyższy gejzer zimnej wody na świecie. Koblencja jest bardzo dobrze funkcjonującym miastem pod każdym względem oraz ma bogatą ofertę usługowo-turystyczną.

Historia miasta na przestrzeni wieków jest burzliwa, ze względu na liczne konflikty zbrojne związane ze strategiczną lokalizacją. Pierwsze wzmianki na temat miasta pochodzą z 1000 roku p.n.e. (dzięki czemu uważa się Koblencję za jedno ze starszych miast Niemiec). Wzniesiono wówczas pierwsze elementy fortyfikacji na wzgórzu, obecnie nazywanym Ehrenbreitstein. W późniejszym czasie, a dokładnie w 55 roku p.n.e., rzymskie wojska dotarły do Renu i wybudowały pierwszy most pomiędzy Koblencją i Andernach. Przez okres panowania cesarstwa rzymskiego wiele razy wznoszono różnego rodzaju budowle i konstrukcje, a ich pozostałości można oglądać po dziś dzień. W okresie średniowiecza Koblencja została podbita przez Franków. Co ciekawe, to tutaj omówiono z karolińskimi dziedzicami przyszłość kraju, czego efektem był traktat z Verdun² (843 r.). W Koblencji w IX wieku odbywały się również liczne synody kościelne. W latach 1249-1254 arcybiskup Arnold II Isenburg wydał 
polecenie stworzenia nowych murów miasta, co częściowo było związane z protestem obywateli, którzy sprzeciwiali się ciągłemu wzmacnianiu płaskowyżu fortecy Ehrenbreitstein. W XVII wieku spustoszenie wojny trzydziestoletniej dotarło również do Koblencji. Miasto było wielokrotnie zdobywane i odzyskiwane, czego efektem było bombardowanie starego miasta przez Francuzów. Wśród zniszczonych budynków była Stara Hala Kupców, która została zrekonstruowana w 1725 roku. Schyłek wieku XVII to stałe rozszerzanie i usprawnianie miasta. W 1786 roku arcybiskup Clemens Wenceslaus przekształcił architekturę budynków Ehrenbreitstein w barokowy pałac. Następnie wielokrotnie była zdobywana i przejmowana, kolejno przez Francuzów, Prusaków, Niemców. W XIX wieku uważany za jeden z silniejszych systemów obronnych w Europie. Jednak główne zmiany w strukturze miasta przyszły podczas II wojny światowej, zostało zniszczone aż 87\% zabudowy, w tym niestety część zabytkowego starego centrum (il. 1). W efekcie działań wojennych straciło życie 80\% mieszkańców. W kwietniu 1945 roku populacja wynosiła nieco ponad 19 tysięcy. W wyniku zmian administracyjnych dotyczących włączenia sąsiednich wsi oraz strategii własnościowych, które stały się atrakcyjną ofertą dla potencjalnych nowych mieszkańców, do 1970 roku ludność wzrosła do 120 tysięcy. Wg danych z 2014 roku największą grupę zagranicznych mieszkańców stanowią Turcy (1525 osób), na drugim miejscu są Polacy (849 osób), na trzecim Rosjanie (572 osoby).

Twierdza Ehrenbreitstein to drugi co do wielkości system fortyfikacji (po Twierdzy Modlin). Projektantami twierdzy byli gen. Ernst von Aster oraz gen. Gustav von Rauch. Twierdza została wybudowana w latach 1817-1828 przez prusaków na wysokim wzgórzu nad Renem. W przypadku wojny miała być wyposażona w 80 dział oraz załogę liczącą 1500 żołnierzy. Po deklasyfikacji twierdzy (1890 r.), na mocy traktatu wersalskiego, obiekt miał zostać rozebrany, jednakże Henry Allen na Wojskowej Komisji ds. Fortyfikacji w Berlinie (1922 r.) zwrócił uwagę na znaczenie kulturowe twierdzy. W 1977 roku na terenie obiektu został odsłonięty pomnik upamiętniający żołnierzy Armii Niemieckiej poległych podczas pierwszej oraz drugiej wojny światowej.

\subsection{STRUKTURA MIASTA A TWIERDZA W UJĘCIU HISTORYCZNYM}

Struktura urbanistyczna jest zwarta w obrębie starego miasta, którego rdzeń stanowi twierdza wojskowa wraz z wzniesieniem Ehrenbreitstein (czerwony obrys - il. 2). Obecnie większość wałów fortyfikacyjnych została zniwelowana i zagospodarowana pod nowe funkcje, przede wszystkim mieszkaniową i usługową. Niewątpliwym atutem założenia jest zieleń, która w gęstej zabudowie dodaje „oddechu” i zmienia postrzeganie miasta.

Porównując ilustracje, na przestrzeni blisko 120 lat widać znaczącą różnicę w stopniu urbanizacji, która bezpośrednio przekłada się na intensywność zabudowy (il. 2 i 3). Powyższe zestawienie pokazuje, jak twierdza została wchłonięta do struktury miasta, m.in. poprzez naturalny rozrost i wysoki stopień inwestycji. Natomiast płaskowyż z cytadelą (il. 2) nie został zabudowany - wręcz przeciwnie, to otwarta przestrzeń, która obecnie służy jako teren do 
uprawiania sportu i rekreacji dla mieszkańców Koblencji. Układ kompozycyjny jest mocno zdefiniowany przez naturalne bariery - dwie rzeki - oraz przez pierwotny system fortyfikacji Koblencji. Analizując Koblencję, należy wziąć pod uwagę skutki II wojny światowej, w efekcie której zniknęła większość istniejącej zabudowy. Głównymi determinantami kompozycji miasta stały się nie tylko rzeki, ale też arterie komunikacyjne, które dzielą Koblencję na dzielnice. Na zachód od miasta zlokalizowana jest autostrada autobahn A61 prowadząca m.in. do Frankfurtu i Kolonii. Transport koleją umożliwia sprawne dotarcie do Bonn i Moguncji.

\subsection{WSPÓŁCZESNE DZIAŁANIA REWITALIZACYJNE}

Ze względu na malownicze położenie twierdza Ehrenbreitstein nazywana jest bramą do Górnej Doliny Środkowego Renu, a jej rangę doceniło UNESCO, wpisując całość regionu na listę światowego dziedzictwa ${ }^{3}$. Płaskowyż oddzielony „zielonymi” urwiskami dominuje nad otoczeniem, tworząc tym samym charakterystyczną linię horyzontu miasta (il. 4). Zróżnicowana topografia terenu oraz naturalne bariery były wyzwaniem dla władz Koblencji, która w procesie rewitalizacji za nadrzędny cel stawiała scalenie miasta. W konsekwencji zaproponowano kolejkę gondolową, która w sposób ekologiczny łączy historyczne centrum z płaskowyżem Ehrenbreitstein. Trasa została wytyczona nad Renem, co niewątpliwie czyni przejazd jedną z większych atrakcji dostępnych w mieście. Na szczególną uwagę zasługuje górna stacja kolejki linowej. Projekt został wykonany przez Doppelmayr - znaną firmę specjalizującą się w górskich kolejkach linowych (parametry techniczne pozwalają na transport 7600 osób na godzinę). Od 2010 roku kolejka jest największym powietrznym tramwajem w Niemczech.

W kwietniu 2011 roku miało miejsce wielkie otwarcie BUGA (Bundesgartenschau), co było największym przedsięwzięciem w historii Rheinland-Pfalz (il. 5 i 6). W pokazie na przestrzeni 7 miesięcy wzięło udział ponad 3,5 miliona osób, co czyni pokaz najbardziej udanym w historii BUGA (w okresie od wprowadzenia elektronicznego systemu liczenia w 1997 roku). Rząd Koblencji sam zgłosił miasto jako miejsce dla najbardziej znanego na świecie pokazu ogrodniczego.

Projekt zagospodarowania wzniesienia oraz obszarów przeznaczonych do Bundesgartenschau drogą konkursu został wykonany przez RMP Landschaftsarchitekten (w latach 20062011) $)^{4}$ na zlecenie BUGA Koblenz 2011 GmbH i.L. Budżet projektu wynosił 29 milinów euro, z czego 1,1 miliona euro przeznaczono na płaskowyż Ehrenbreitstein. Zgodnie z ideą architektów działania projektowe traktowane są jako preludium z długoterminowym efektem - od twierdzy po lokalne przestrzenie kultury i wypoczynku. Stworzono niezbędne warunki do rekultywacji dawnej bazy wojskowej. Budynki twierdzy zostały zaadaptowane pod nowe funkcje, znajdują się tam m.in.: Muzeum z 4 stałymi wystawami, wielofunkcyjne sale multimedialne (umożliwiające zorganizowanie konferencji), ogródek piwny, winiarnia, restauracja, hostel, platforma widokowa oraz górna stacja kolei gondolowej. W otoczeniu odnowionych, zabytkowych budynków na placu jest możliwość zorganizowania imprez plenerowych bądź cyklicznych pokazów upamiętniających poległych żołnierzy (np. symboliczny strzał z armat). Otwarty obszar przed cytadelą, 
obecnie miejsce sportu i rekreacji, zostało zaprojektowane w sposób przejrzysty kompozycyjnie i funkcjonalny. Proste ścieżki łączą najważniejsze punkty komunikacji w przestrzeni, tzn. wjazd dla samochodów i parking, górną stację kolejki gondolowej, platformę widokową, wejście do budynków twierdzy; tworząc tym samym najszybsze połączenia. Ze względu na przewidywany ruch, w miejscach o większym natężeniu odpowiednio poszerzono trakty, co automatycznie zwiększa przepustowość danej ścieżki. Zagospodarowanie wewnętrznych pól, wytyczonych przez alejki, jest zróżnicowane rodzajem zieleni, a w paru miejscach proponowaną funkcją - fontanny, wystawy plenerowe. To podejście godne naśladowania, w szczególności w odniesieniu do rozwiązań przestrzennych gwarantujących elastyczność proponowanych funkcji. W przypadku całkowitego bądź częściowego zabudowania obszaru nie byłoby możliwości stworzenia ww. wydarzeń kulturalnych. Co ciekawe, twierdza, która była przeznaczona do rozbiórki, na przekór stała się istotą rozwoju miasta w kontekście nowej jakości przestrzeni miejskiej.

Wytyczono 3 główne obszary: płaskowyż twierdzy Ehrenbreitstein, Blumenhof-Deutsches Eck (ujście Mozeli do Renu - obszar 2,2 hektara) oraz Schlosspark (przed pałacem wyborczym - 8,6 hektara), z czego największym jest właśnie teren parku fortyfikacji - 27 hektarów - obszar zbliżony do cytadeli Twierdzy Modlin z pierwszym obwodem wałów - 34 hektary (il. 7). W opisie do planu znajduje się aż 90 atrakcji, m.in. gaj orchidei, winnice, sady i ogrody, miejsca rzadkich gatunków nietoperzy i innych zagrożonych gatunków. Zaproponowano wiele funkcji uzupełniających dla szerokiego przekroju odbiorców (tor dla rolkarzy, place zabaw dla dzieci, pawilony wystawiennicze itp.). Analizując plan BUGI 2011, można przywołać działania z zakresu akupunktury urbanistycznej ${ }^{5}$ w odniesieniu do „zielonych" traktów, gdzie poprzez strategiczne punkty miasta tworzy się wewnętrzny obwód ścieżki dydaktycznej, rekreacyjnej i wreszcie miejskiej.

Całkowity budżet realizacji projektu wyniósł $102 \mathrm{mln}$ euro ${ }^{6}$, jednak przewiduje się, że wartość wydatków zainwestowanych w rozwój miasta wyniosła $500 \mathrm{mln}$ euro. W efekcie rządowi Koblencji udało się poprawić wizerunek miasta oraz jakość świadczonych usług. W kontekście przywołanych liczb zysk rzędu $13 \mathrm{mln}$ nie jest imponujący, ale należy pamiętać, jak wysoce miasto zostało wypromowane na arenie międzynarodowej i w następstwie stało się nowym celem znacznej liczby turystów.

\section{WNIOSKI}

Twierdza Ehrenbreitstein i jej obecne funkcjonowanie jest bardzo dobrym przykładem wprowadzenia działań projektowych z zakresu rewitalizacji, które na stałe podwyższyły standard życia mieszkańców i zwiększyły znaczenie miasta w kontekście lokalnym oraz ponadlokalnym. Decyzje projektowe zostały podjęte świadomie i są formą „zrozumiałego komunikatu przestrzennego"7 . Przestrzenie otwarte, przed fortyfikacjami, które były tworzone na potrzeby taktyki i strategii prowadzenia bitew, obecnie mogą się stać pretekstem do zostawienia przestrzeni, ale już na potrzeby czasów współczesnych. Pomijając turystyczne 
walory miejsca, to rola zrewitalizowanej twierdzy w strukturze miasta ma przede wszystkim znaczenie społeczne. Jest to miejsce aktywizacji sportowej mieszkańców, ale też kulturowej, co wydaje się być dobrym połączeniem do budowania relacji rodzinnych i interakcji społecznych z innymi mieszkańcami Koblencji. Należy pamiętać o szczególnej roli użytkowników przekształcanego terenu - jako działanie oddolne, muszą być włączani w proces przemiany (partycypacja mieszkańców powinna się odbywać na jasno przedstawionym zamierzeniu projektowym, które będzie determinantą powodzenia przedsięwzięcia), co zaktywizuje społeczność lokalną, a w następstwie poprawi jakość korzystania z przestrzeni. Brak rewitalizacji prowadzi do negatywnego oddziaływania na miasto, czego dowodem jest np. część fortów w Krakowie.

Primum non nocere - po pierwsze nie szkodzić - jedna z naczelnych zasad w medycynie. Można jednak stosować to pryncypium w innych dziedzinach nauki, a w szczególności w architekturze i urbanistyce. Zilustrowaniem tej zasady jest właśnie Twierdza Ehrenbreitstein w Koblencji, która dowodzi, iż można osiągnąć sukces komercyjny, nie zabudowując intensywnie terenu inwestycji. Co więcej, elementy fortyfikacji same już są w sobie wartością, dlatego nie ma potrzeby tworzenia nowych. W kontekście przyszłych inwestycji podjęte działania planistyczno-architektoniczne są prawidłowym ustosunkowaniem się do idei zrównoważonego rozwoju. Proponowana strategia projektowa, z myślą o przyszłych pokoleniach, daje możliwość implementacji elastycznych rozwiązań przestrzennych. Świadomość ciągłej zmiany jest kluczowa i powinna być rozpatrywana w każdym podejmowanym zamierzeniu inwestycyjnym. Ponadto w skali miejskiej działania rewitalizacyjne zaprezentowane w Koblencji mogą być rozumiane jako przewidywalna forma rozwoju miast oraz mogą być sposobem na rozwinięcie zielonych przestrzeni niezbędnych do prawidłowego funkcjonowania struktur urbanistycznych. To punkt wyjścia dla wieloaspektowych interwencji planistyczno-architektonicznych służących polepszaniu kondycji miast.

Efekt dostosowania twierdzy w Koblencji do potrzeb dnia dzisiejszego może służyć jako mocny kontrargument w dyskusjach z deweloperami, którzy coraz częściej inwestują w obszary pomilitarne i nieustannie próbują dogęszczać zabudowę. W kontekście XIX-wiecznych terenów pomilitarnych ważne są działania projektowe wysoce zindywidualizowane, które w efekcie przerodzą się w niestandardowe i unikalne rozwiązania architektoniczno-przestrzenne. Rezultatem tych prac może być właśnie „nowy wymiar sensu miasta”, w którym nadrzędną rolę pełni społeczeństwo i budowanie relacji społecznych. Tereny powojskowe mogą się stać idealnym miejscem do wprowadzenia nowej jakości życia i przestrzeni, która w większości miast, mimo ciągłego polepszania, wydaje się być już zdefiniowana. 


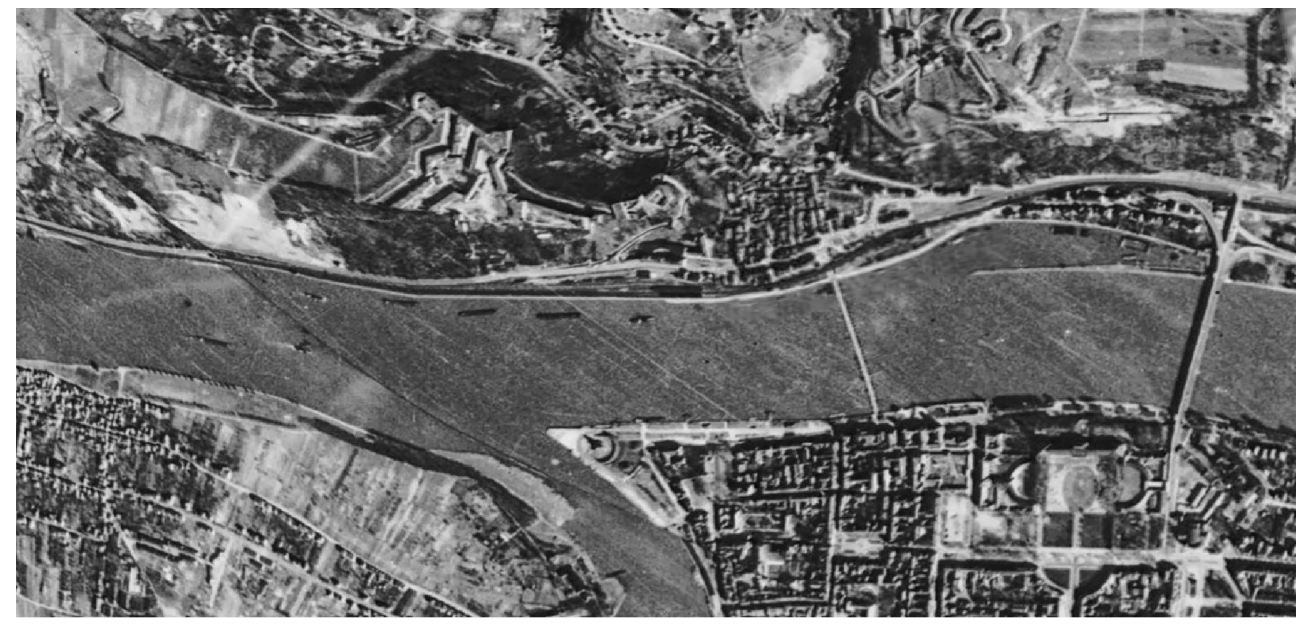

II. 1. Zdjęcie lotnicze z okresu II wojny światowej - pierwsze zniszczenia (źródło: Google Earth)

III. 1. Aerial photograph of the World War II period - first destructions
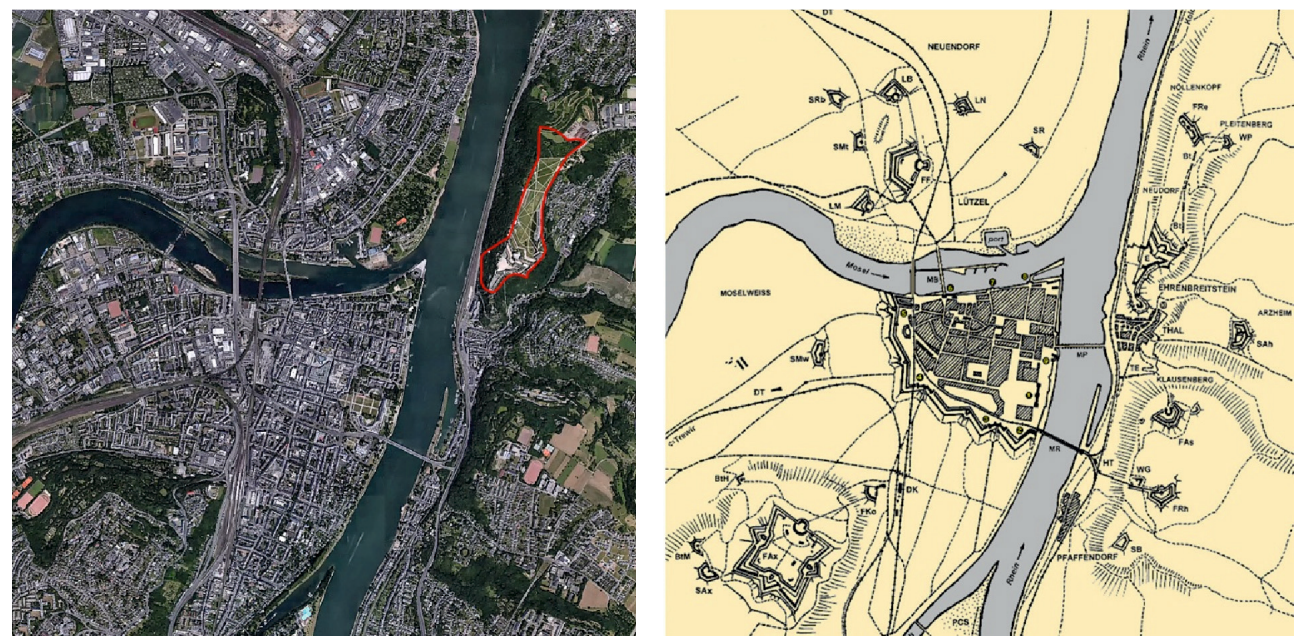

II. 2. Widok satelitarny centrum Koblencji, stan na 2009 rok (źródło: Google Earth)

III. 2. Satellite view of the center of Koblenz, as for year 2009

II. 3. Rysunek układu fortyfikacji Koblencji Mariusza Wojciechowskiego stan na 1890 rok (źródło: mariwoj.pl - dostęp: 20.11.2016)

III. 3. Figure of fortifications in Coblenz. Author Mariusz Wojciechowski, as for year 1890 


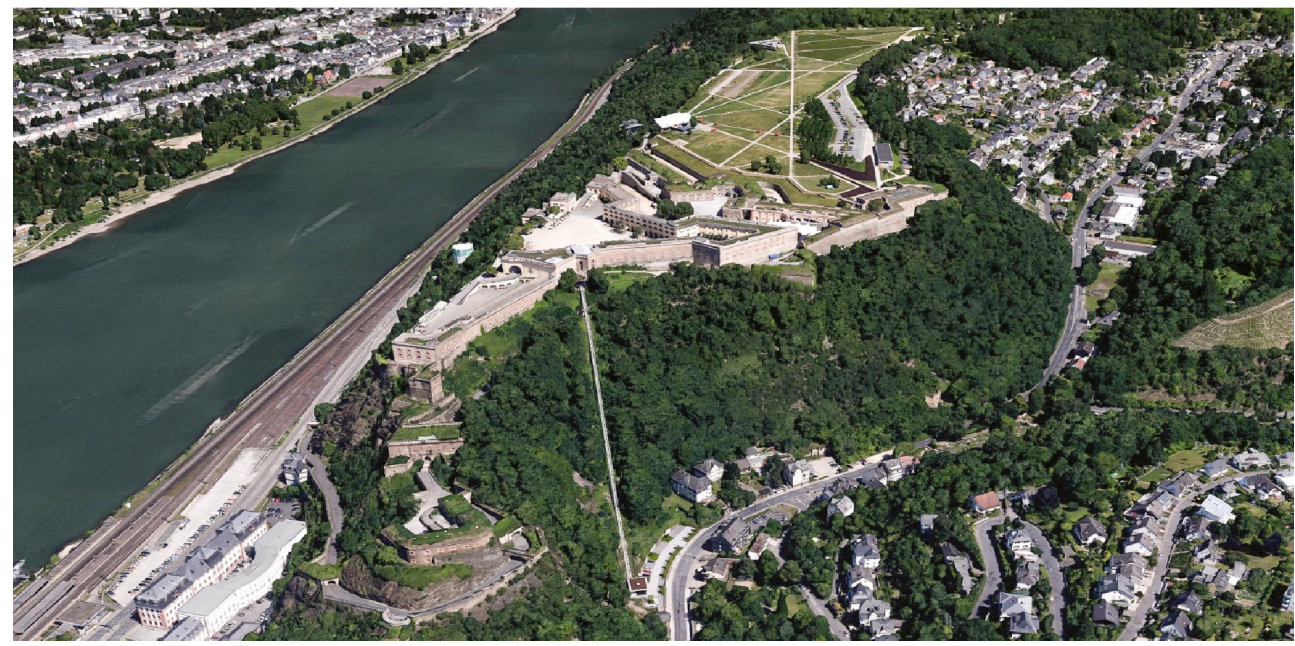

II. 4. Widok od północy na płaskowyż twierdzy Ehrenbreitstein (źródło: Google Earth) III. 4. Northern view at the Ehrenbreitstein plateu
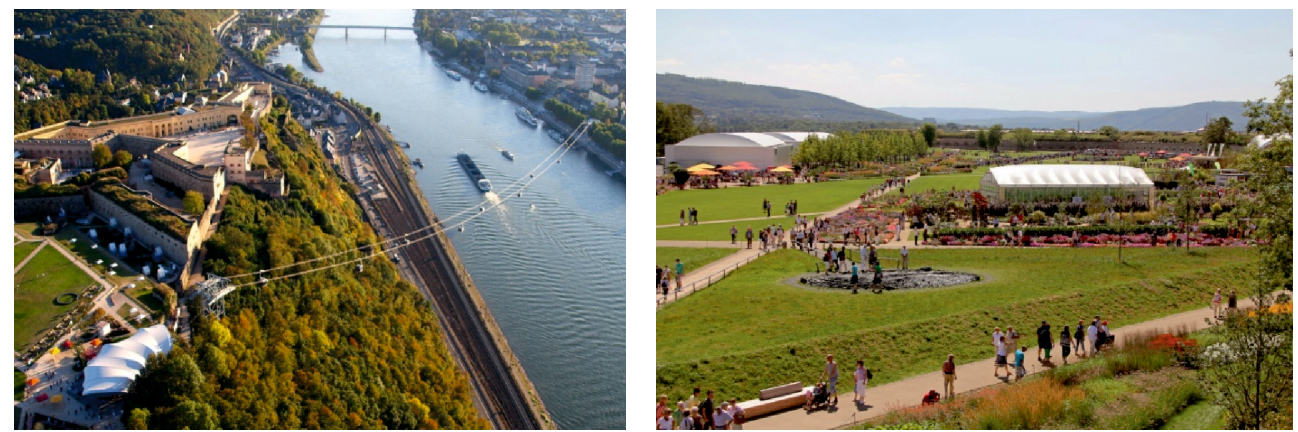

II. 5. Widok z lotu ptaka od południa (źródło: de.wikipedia.org/autor fotografii: Wolkenkratzer dostęp: 27.11.2016)

III. 5. Southern aerail view

II. 6. Widok z BUGA 2011 (źródło: http://commons.wikimedia.org - dostęp: 27.11.2016) 


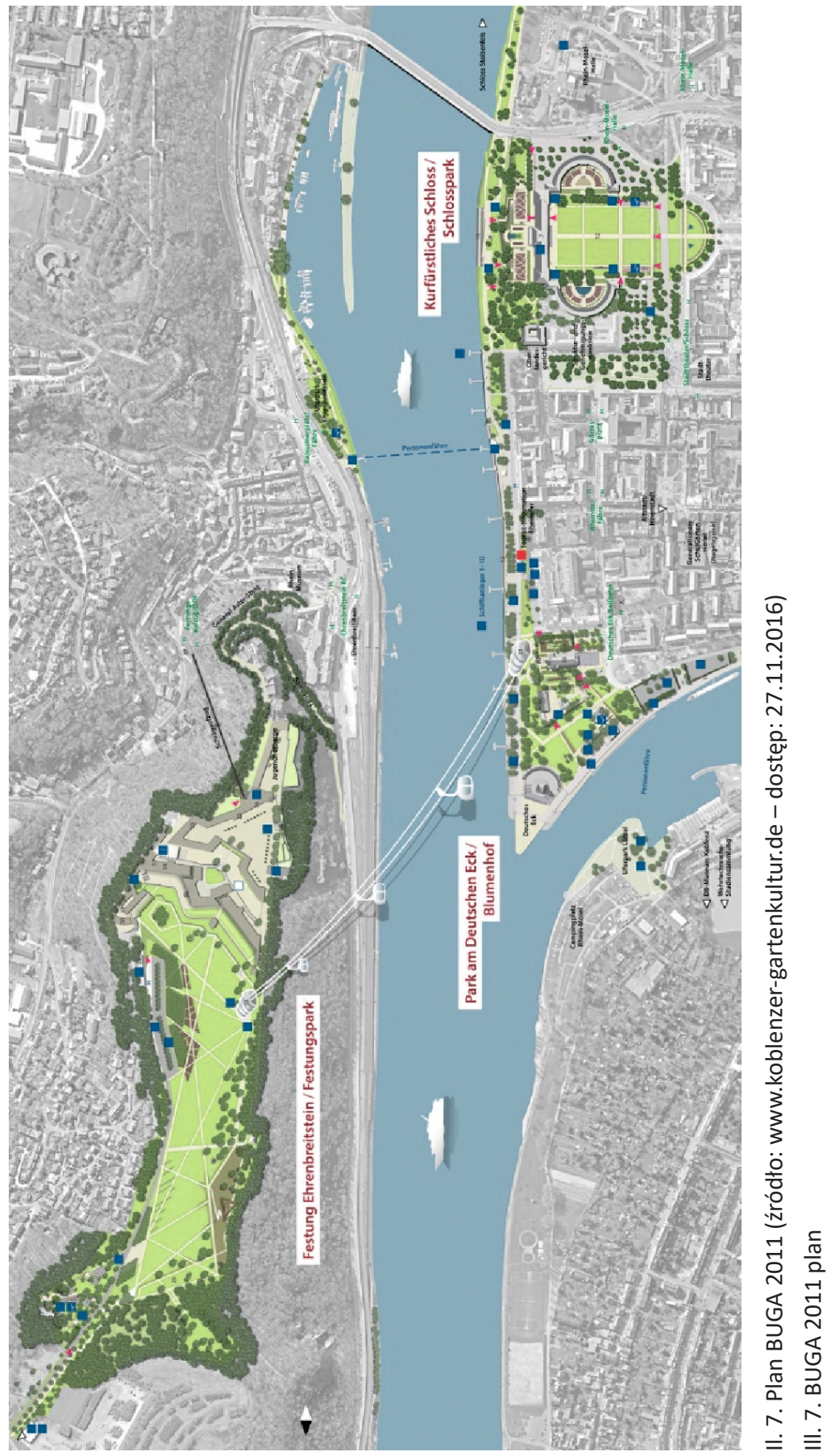




\section{PRZYPISY}

1 Jednym z dowodów na aktualność problematyki jest dokumentacja współfinansowana przez Unię Europejską o tytule: Baltic Cultural and Tourism Route Fortresses, Results of transnational cooperation in INTERREG-III-B Project 2005-2007, Appropriate Monumental use of Fortresses - Documentation and recommended proceeding, Saving of the Cultural Heritage Fortresses. W kategoriach prac badawczych warto odnieść się do prac: Anny Staniewskiej (2009), Katarzyny Pałubskiej (2006; 2007), Cezarego Głuszka (1998).

2 Traktat zawarty w 843 roku w Verdun, który podzielił państwo Karola Wielkiego. Podział ten położył podwaliny pod powstanie w przyszłości Francji i Niemiec.

3 Oficjalnego wpisu dokonano w 2002 roku. To 65-kilometrowy odcinek Górnej Doliny Środkowego Renu biegnący wzdłuż Renu od Koblencji po Bingen.

4 Cały obszar rewitalizacji wynosi 64 hektary, natomiast plateu 16 hektarów, z czego 9 hektarów zaplanowano przez RMP Stephan Lenzen Landschaftsarchitekten. Biuro wygrało I nagrodę w konkursie z von Canal Architekten \& Ingenieure.

5 Pojęcie również stosowane w pracy dydaktyczno-naukowej przez prof. Annę Frantę w kontekście interwencji planistyczno-architektonicznych, przez które rozumie się szeroko pojęte działania z zakresu poprawy jakości przestrzeni miejskiej w konkretnych punktach miasta, tworzące wspólnie system polepszenia kondycji miasta w sensie społecznym, estetycznym oraz funkcjonalnym.

6 Dane z internetowego archiwum Bundergartenshau 2011.

7 Jan Wrana, Tożsamość miejsca, kryterium w projektowaniu architektonicznym, Wydawnictwo Politechniki Lubelskiej, Lublin 2011, s. 172.

\section{BIBLIOGRAFIA}

\section{Wydawnictwa książkowe}

Bogdanowski J., Krajobraz warowny XIX/XX w.: dzieje i rewaloryzacja, Kraków 1993.

Pałubska K., Analiza historyczno-przestrzenna oraz własnościowa pod kątem utworzenia parku kulturowego zespołu fortyfikacji XIX-wiecznej Twierdzy Warszawa, mps. Opracowanie dla Urzędu m. st. Warszawy - Biura Stołecznego Konserwatora Zabytków, Warszawa 2007.

Wrana J., Tożsamość miejsca, kryterium w projektowaniu architektonicznym, Wydawnictwo Politechniki Lubelskiej, Lublin 2011.

von Berg A., Archäologische Untersuchungen im Bereich der "Großen Traverse" auf der Festung Ehrenbreitstein, Koblenz (German); [in:] Archäologie in Rheinland-Pfalz 2004. Verlag Phillip von Zabern, 2005, ISBN 978-3805335515.

Böckling M., Festung Ehrenbreitstein (German). Schnell + Steiner, Regensburg, 2004, ISBN 9783795414436. 
Burgen, Schlösser, Altertümer Rheinland-Pfalz (ed.). Neue Forschungen zur Festung Koblenz und Ehrenbreitstein, Band 1 (German). Schnell + Steiner, 2005, ISBN 978-3795417642.

Deutsche Gesellschaft für Festungsforschung e.V. (ed.). Neue Forschungen zur Festung Koblenz und Ehrenbreitstein, Band 3 (German). Schnell + Steiner, 2012, ISBN 978-3795424756.

Wischemann Rüdiger, Die Festung Koblenz (German), 1978, ISBN 978-3795414436.

\section{Czasopisma}

Rewitalizacja Obszarów Miejskich, Praktyczny przewodnik: Jak opracować lokalny plan rozwoju?, Carl A. Heller.

\section{Rozdziały}

Weiss P., Die Bergung von Kulturgütern auf der Festung Ehrenbreitstein (German); in: Jahrbuch für westdeutsche Landesgeschichte 26, 2000, s. 421-452.

\section{Prace zbiorowe}

Baltic Cultural and Tourism Route Fortresses, Results of transnational cooperation in INTERREG-III-B Project 2005-2007, Appropriate Monumental use of Fortresses - Documentation and recommended proceeding, Saving of the Cultural Heritage Fortresses.

Rewitalizacja miast w Niemczech, Tom 3, M. Bryx, A. Jadach-Sepioło (red.), Instytut Rozwoju Miast, Kraków 2009.

\section{Strony internetowe}

http://www.diefestungehrenbreitstein.de/ (dostęp: 28.11.2016).

http://www.seilbahn-koblenz.de/ (dostęp: 28.11.2016).

http://www.koblenz-touristik.de/kultur/sehenswertes-koblenz/festung-ehrenbreitstein.html (dostęp: 07.12.2016).

http://commons.wikimedia.org (dostęp: 27.11.2016).

http://www.rmpsl.la (dostęp: 26.12.2016). 